\section{Multidetector CT Findings of Solid Organ Injury Based on 2018 Updated American Association for the Surgery of Trauma Organ Injury Scaling System \\ 2018 개정 미국외상수술협회 복부고형장기 손상척도에 따른 다중검출 CT 소견}

Hyo Hyeon Yu, MD (D), Yoo Dong Won, MD* (D), Su Lim Lee, MD (D), Young Mi Ku, MD (D), Sun Wha Song, MD (D)

Department of Radiology, Uijeongbu St. Mary's Hospital, College of Medicine, The Catholic University of Korea, Seoul, Korea

The newly revised 2018 Organ Injury Scale (OIS) has a similar format to the previous American Association for Surgery and Trauma (AAST) Emergency General Surgery Grading System, dividing the criteria for grading solid organ damage into three groups; imaging, operation, and pathology. The most significant alteration in the OIS system 2018 revision is the incorporation of multidetector $\mathrm{CT}$ (MDCT) findings of vascular injury including pseudoaneurysm and arteriovenous fistula. Similar to the previous OIS, the highest of the three criteria is assigned the final grade. In addition, if multiple grade I or II injuries are present, one grade is advanced for multiple injuries up to grade III. This pictorial essay demonstrates the MDCT findings of solid organ injury grades based on the 2018 OIS system.

Index terms Abdominal Injuries; Blunt Injuries; Multidetector Computed Tomography; Injury Severity Score
Received March 2, 2020

Revised March 17, 2020

Accepted March 31, 2020

${ }^{\star}$ Corresponding author

Yoo Dong Won, MD

Department of Radiology,

Uijeongbu St. Mary's Hospital,

College of Medicine,

The Catholic University of Korea,

271 Cheonbo-ro,

Uijeongbu 11765, Korea.

Tel 82-31-820-5004

Fax 82-31-846-3080

E-mail yoodong1@catholic.ac.kr

This is an Open Access article distributed under the terms of the Creative Commons Attribution Non-Commercial License (https://creativecommons.org/ licenses/by-nc/4.0) which permits unrestricted non-commercial use, distribution, and reproduction in any medium, provided the original work is properly cited.

\section{ORCID iDs}

Hyo Hyeon Yu (D) https://

orcid.org/0000-0001-6271-420X

Yoo Dong Won (D)

https://

orcid.org/0000-0002-4422-591X

Su Lim Lee (D)

https://

orcid.org/0000-0001-7109-353X

Young Mi Ku (D)

https://

orcid.org/0000-0002-6212-1110

Sun Wha Song $(\mathbb{D}$

https://

orcid.org/0000-0002-8962-0729 
안되었고(1), 이후에 1994년 한차례 개정되었다(2). AAST OIS는 임상연구, 외상 환자들의 위험도 평가, 치료, 예후 등을 결정하는데 널리 이용되어 왔다. OIS에 도입 이후에 외상 환자의 진단과 분 류에 있어 다중검출 CT (multidetector CT; 이하 MDCT) 사용의 증가와 함께 비수술적인 치료에 초점을 두어 발전하여 왔다. 이런 환경 변화를 반영하여 AAST는 2018년에 다시 한번 더 개정되 었다(3).

2018년에 새롭게 개정된 OIS는 이전 AAST Emergency General Surgery Grading System과 유사한 형식을 가지며, 고형장기 손상의 등급을 지정하는 기준을 영상(imaging), 수술(operative), 병리(pathologic) 3 가지 세트로 나누어 분류하였다(4). 2018년 개정에서 가장 중요한 변화는 거짓동맥류와 동정맥 누공을 포함한 혈관 손상의 $\mathrm{MDCT}$ 소견을 정의하여 OIS에 통합한 것이다.

Fig. 1. Contained vascular injury in a 20-year-old-man after a motorcycle accident.

A. Arterial phase (left image) and delayed phase (right image) of the contrast-enhanced axial CT scans demonstrate a contained vascular injury (arrows) that decreases in attenuation with delayed imaging and display the same density as the adjacent vessels in the delayed phase. A hemoperitoneum is evident in the right subphrenic space.

B. Left hepatic angiograms of embolization reveal a pseudoaneurysm (arrows) combined with contrast extravasation (arrowhead, right image) that was not detected on the initial CT scan.
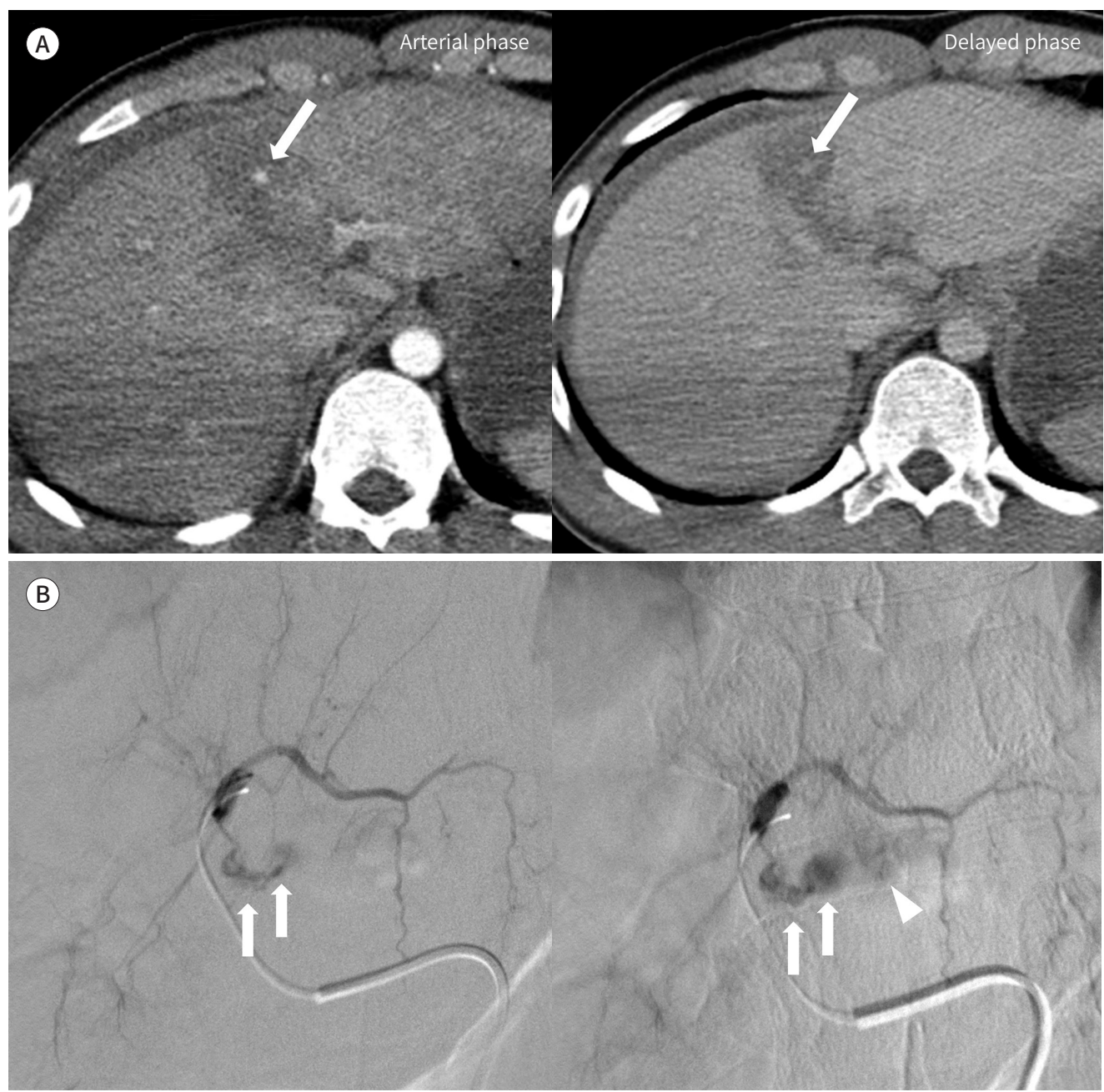
이전 OIS와 동일하게 세 가지 기준 중에 가장 높은 등급이 최종 등급이 된다. 또한 한 장기 내에 여 러 개의 1 등급 또는 2 등급 소견이 있으면, 다발성 손상에 대해 3 등급의 부여가 가능하다. 본 임상 화보에서는 2018년 개정된 AAST OIS의 영상 등급의 MDCT 소견을 소개하고자 한다.

\section{AAST OIS 2018년도 개정판의 주요 변화}

AAST OIS 2018 개정안의 가장 중요한 변화는 MDCT로 진단 가능한 혈관 손상이 OIS 등급에 포함되었다는 것이다(5-7). 거짓동맥류(pseudoaneurysm)와 동정맥루(arteriovenous fistula)를 포함하는 혈관 손상은 MDCT에서는 동일한 소견을 보이나 혈관조영술에서는 구분이 가능하다 (Fig. 1). MDCT에서 혈관 손상은 동맥기에서 높은 음영의 조영제가 차 있는 국소적인 원형 또는 타원형의 병변으로 보이고, 문맥기 및 지연기 영상에서는 병변의 음영이 감소하여 주변의 혈관과 음영이 같아진다(Fig. 1). 혈관 손상으로 인한 지속적인 출혈은 동맥기에서 국소적인 혹은 광범위 한 높은 혈관 음영의 형태로 나타나며, 문맥기 및 지연 영상으로 갈수록 그 크기와 음영의 강도가 증가한다(Fig. 2). 지속적인 출혈은 장기 내에만 국한될 수 있지만, 피막 손상을 동반한 경우, 손상 된 장기를 넘어서 혈복강이 동반될 수도 있다(8). 이전의 여러 문헌들에 따르면 혈관 손상이 존재 할 경우, 보존적 치료는 높은 실패율을 보고하고 있다(9-23). OIS 2018 개정안은 비록 치료적인 전 략에 대해서는 다루고 있지 않지만, 앞에서 설명한 거짓동맥류나 동정맥루 같은 혈관 손상이나 지

Fig. 2. The ACE and contained vascular injury of a 20-year-old man after a motorcycle accident.

Multiphase axial CT images show ACE in a branch of the splenic artery (white arrows) that gradually increased in size and density over the portal and delayed phases. In contrast, contained vascular injury lesions in the spleen show the same density as the adjacent vessel in all phases (black arrows).

$\mathrm{ACE}=$ active contrast extravasation

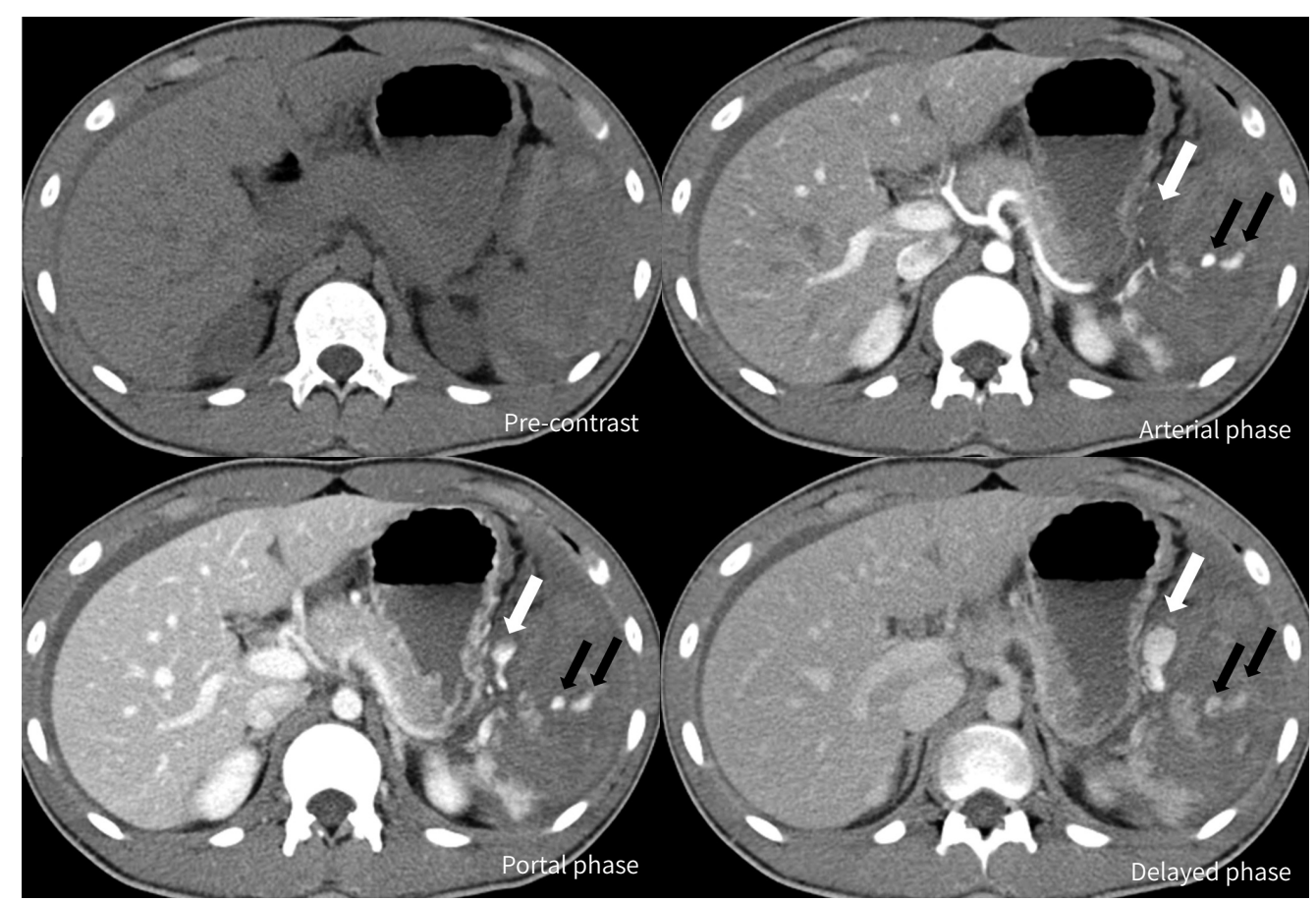


속적인 출혈이 있는 경우에는 높은 영상 기준등급을 부여하여, 혈관색전술(transcatheter embolization)을 포함한 응급 치료의 시행 여부를 결정하는 데 도움을 준다(4). 따라서 혈관 손상을 OIS 등급에 포함하는 것은 치료 방법의 선택에 있어 매우 의미 있는 변화이며 앞으로 개정된 OIS에 따 른 표준 치료 전략의 정립이 필요하다.

\section{MDCT 촬영 방법}

복부 외상 환자에서 MDCT는 초음파와 함께 가장 중요하고 널리 쓰이는 영상 진단 도구이다. 각 기관에 따라 복부 외상 환자에 대한 MDCT 프로토콜은 다르겠지만, 일반적으로 경정맥 조영제 를 사용하여 다중시기 촬영(multi-phase imaging)을 하는 것이 널리 이용되고 있다. 경정맥 조영 제 주입 후 얻은 문맥기 영상은 복부 장기의 실질이 가장 잘 조영되는 영상이다. 따라서 문맥기 영 상은 복부고형장기의 손상을 가장 잘 발견할 수 있는 영상이기 때문에 필수적으로 이용된다. 문맥

Fig. 3. Ruptured subcapsular and parenchymal hepatic hematoma (grade III) of a 26-year-old man after a motor vehicle accident with a seat belt injury.

A. Contrast-enhanced axial CT image shows subcapsular and parenchymal hematoma (asterisks) combined with hemoperitoneum in the perisplenic space.

B. Axial (left image) and coronal (right image) reformatted images demonstrate the sentinel clot sign. The Hounsfield units of the subcapsular and intraparenchymal hematoma are higher than those of the pelvic cavity and the perisplenic hemorrhage, indicating that the damaged liver is the bleeding site.
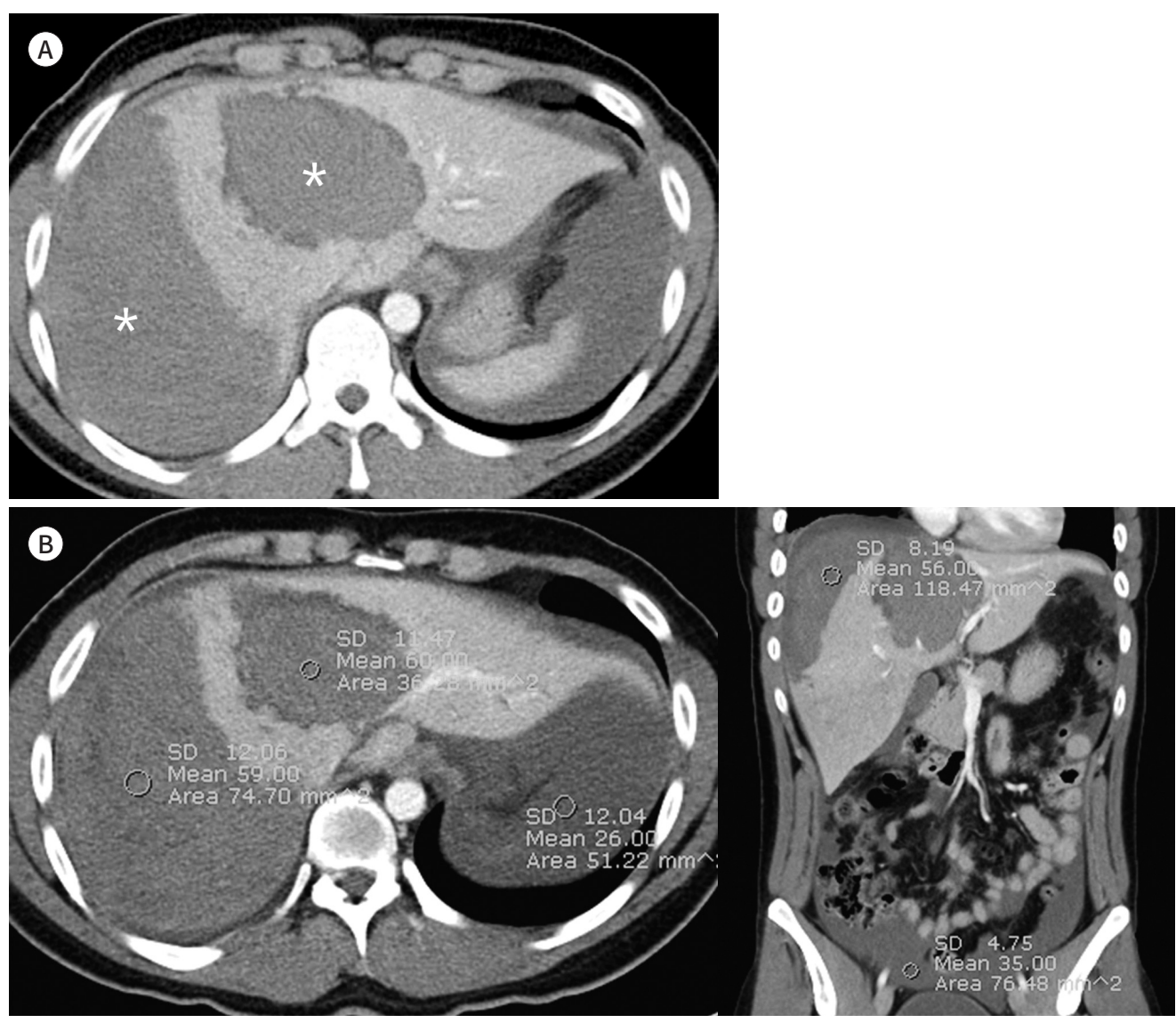
기 영상은 복부고형장기의 실질 손상뿐만 아니라, 혈관 손상 동반 여부도 확인할 수 있지만, 영상 획득 시기에 따라서 실제로 혈관 손상이 있더라도 문맥기 영상에서는 관찰되지 않을 수 있기 때문 에 동맥기 영상 역시 필수적으로 널리 이용된다. 5 분 지연기 영상은 요로 손상의 발견에 용이하기 때문에, 요로 손상이 함께 의심될 경우에 선택적으로 이용된다. 하지만 다중시기 촬영을 시행할 경우 방사선량이 증가하는 문제가 있기 때문에 방사선량은 줄이면서 진단의 정확도를 높이려는 시도가 여러 연구에서 진행되고 있다. 최근 Leung 등(24)에 의한 연구에서, 문맥기 영상을 위해 1 차적으로 조영제를 주입하고, 1 차 조영제 주입 10 초 후 2 차적으로 조영제를 주입하여 한 번의 CT 스캔으로 장기의 실질 손상과 혈관 손상을 잘 관찰할 수 있는 영상을 획득하는 프로토콜(spilt bolus protocol)을 시행하였고, 이를 통해 진단의 정확성을 높이면서 동시에 노출되는 방사선량도 감소시킬 수 있다고 보고하였다 $(24,25)$. 특히 외상 센터를 가지고 있는 병원들의 경우, 외상 환자 의 많은 수가 건강한 젊은 사람이라는 것을 고려하여, 방사선량을 줄이기 위한 노력과 연구를 계 속하여야 할 것이다.

\section{복부 외상 환자의 주요 MDCT 소견}

\section{실질 손상}

실질 손상에는 열상(laceration), 둔상(contusion), 골절(fracture)이 있다. 열상은 실질의 손상 이 장기의 표면까지 닿아 피막의 손상이 있는 경우이고, 둔상은 실질의 손상은 있지만 피막의 손 상은 없는 경우이다. 골절은 열상이 장기의 한쪽 끝에서 다른 한쪽 끝까지 전체 두께로 있는 경우 이다.

\section{혈관 손상}

혈관 손상은 국한(contained) 혈관 손상과 비국한(non-contained) 혈관 손상으로 나뉜다.

국한 혈관 손상에는 앞서 서론에서 설명한 거짓동맥류와 동정맥루가 있다. 여기서 국한의 의미

Fig. 4. Parenchymal hematoma and laceration of the spleen (grade III) with rib fracture in a 24-year-old man after a motor vehicle accident.

A. Contrast-enhanced axial CT scan shows parenchymal hematoma (asterisk), perisplenic hematoma (arrows), and an irregular and linear low-attenuation area (arrowhead) in the spleen consistent with a laceration. B. Contrast-enhanced coronal CT scan shows the parenchymal hematoma (asterisk) and the perisplenic hematoma (arrow).
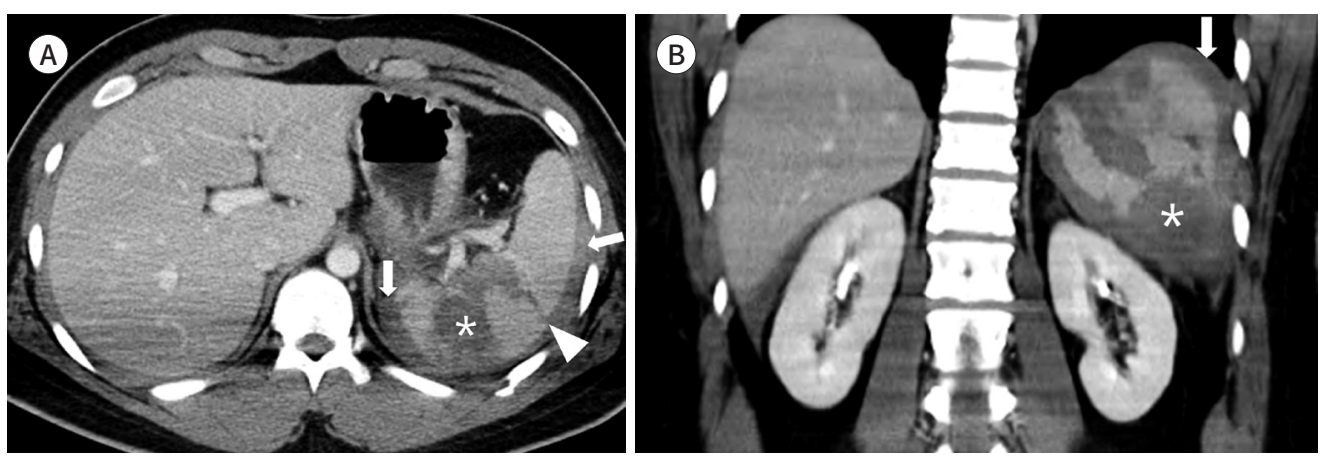
는 장기 내부의 국한된 손상을 의미하는 것이 아니라 경정맥 조영제를 이용한 MDCT 검사에서 조 영제가 혈관 밖으로 새어 나가지 않고 혈관 내에만 국한되어 있는 소견을 가지는 혈관 손상을 의 미한다(Figs. 1, 2).

비국한 혈관 손상에는 조영제의 혈관 외 유출(active contrast extravasaion)이 대표적이다. 동

Fig. 5. Incidental finding of spleen cleft (arrowhead) in a 69-year-old man.

A, B. The contrast enhanced axial (A) and coronal (B) CT scans. In contrast to a laceration, a cleft has a sharp margin, containing fat and is not associated with an adjacent subcapsular hematoma or perisplenic fluid.
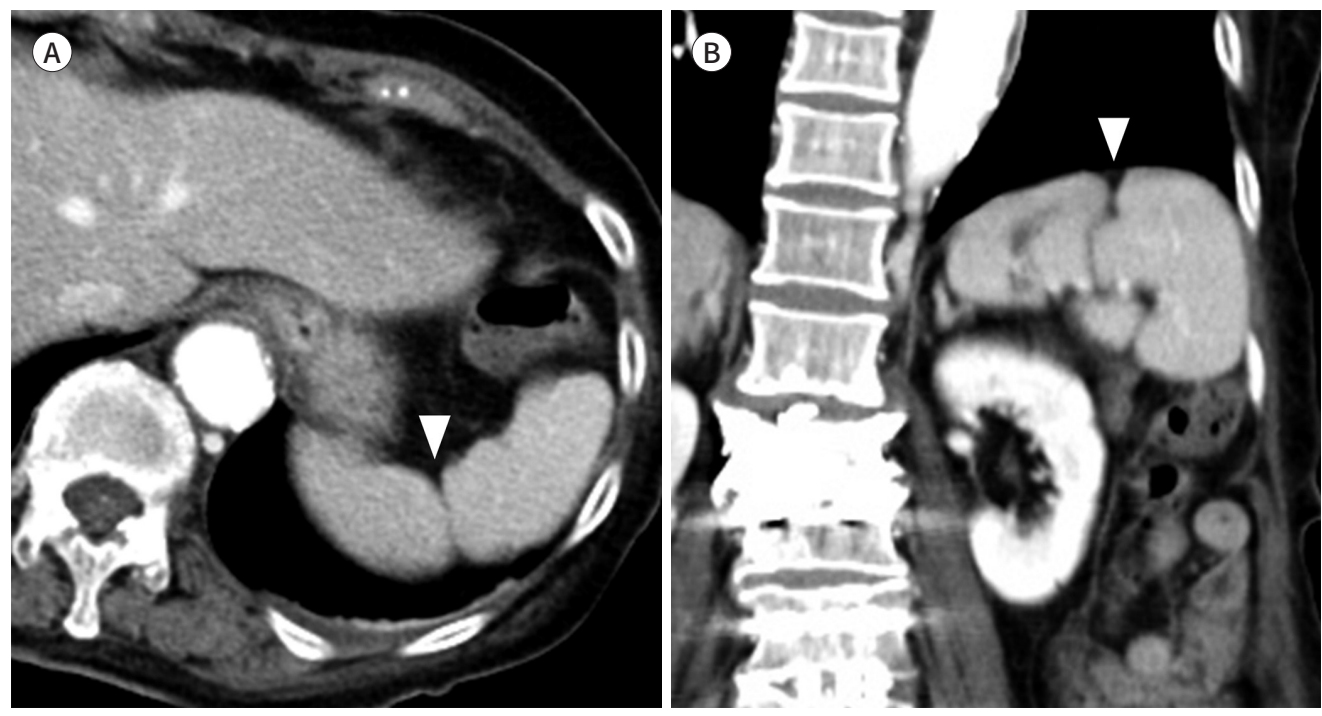

Fig. 6. Contained vascular injury confined to the splenic capsule (grade IV) in a 57-year-old man after a motor vehicle accident.

A, B. The contrast-enhanced axial CT scan (A) and contrast-enhanced coronal CT scan (B) show a pseudoaneurysm confined within the splenic capsule (arrowheads) and perisplenic hematoma (asterisks).
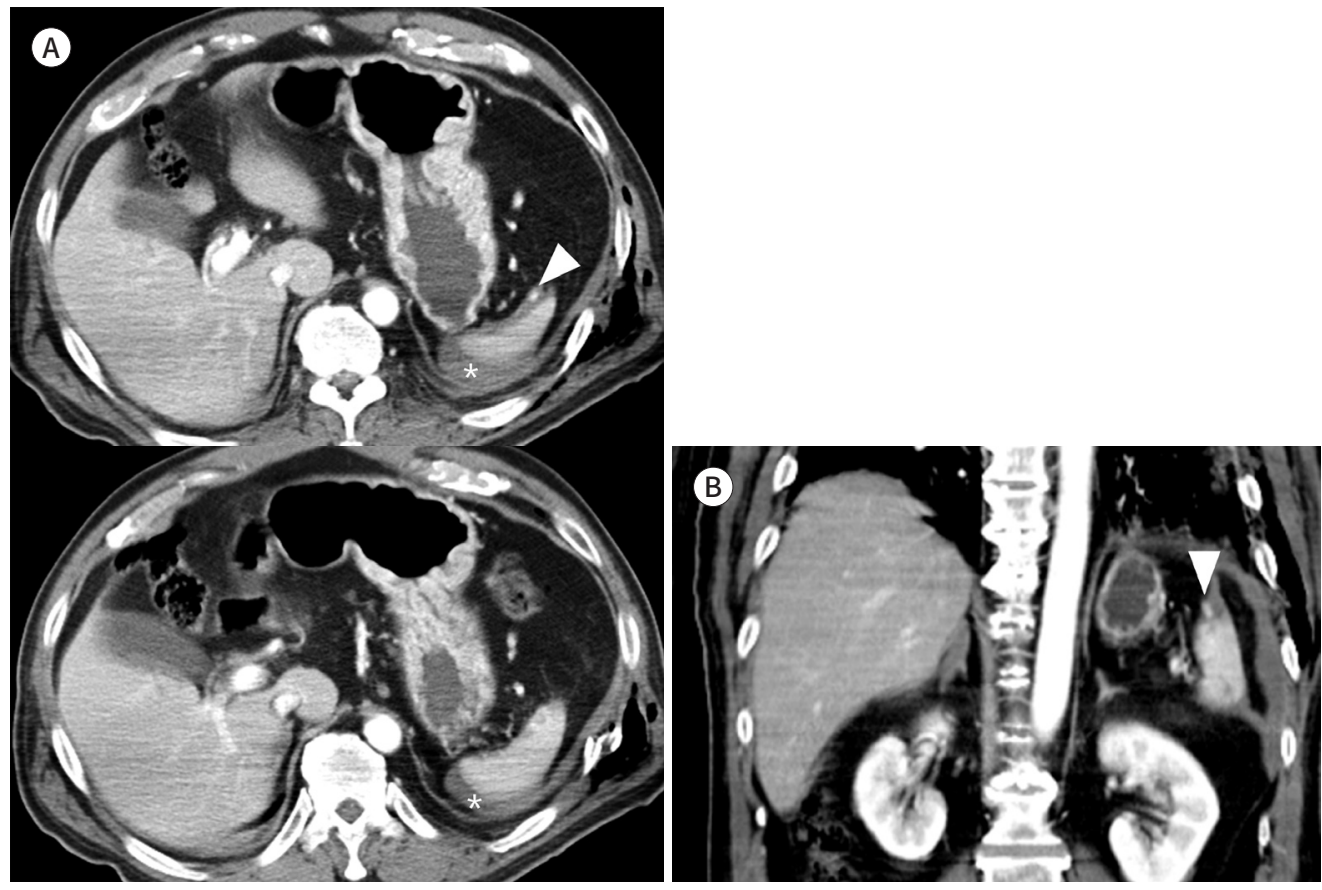
맥 출혈일 경우 감쇠 정도는 동맥기에서 대동맥이나 주요 혈관 내부와 비슷한 음영 강도를 보이고 문맥기에서 문맥기의 대동맥이나 주요 혈관 내부보다 더 높은 음영 강도를 보이는 반면, 정맥 출

Fig. 7. Splenic arterial embolization of a spleen injury (grade IV) in a 54-year-old man after a fall.

A. Arterial phase (left image) and portal phase (right image) contrast-enhanced axial CT scans show ACE in the spleen (arrows). More than 50\% of the spleen is infarcted on this CT scan.

B. Splenic artery angiograms show multiple ACE (arrowheads, right image) in the superior segment of the splenic artery.

C. Post-embolization splenic arteriogram reveals no further ACE, indicating treatment success.

D. Follow-up contrast-enhanced axial CT scan acquired 1 week after splenic artery embolization demonstrates regression of the ACE and hematoma. However, a segmental splenic infarction is noted (asterisk).

$\mathrm{ACE}=$ active contrast extravasation
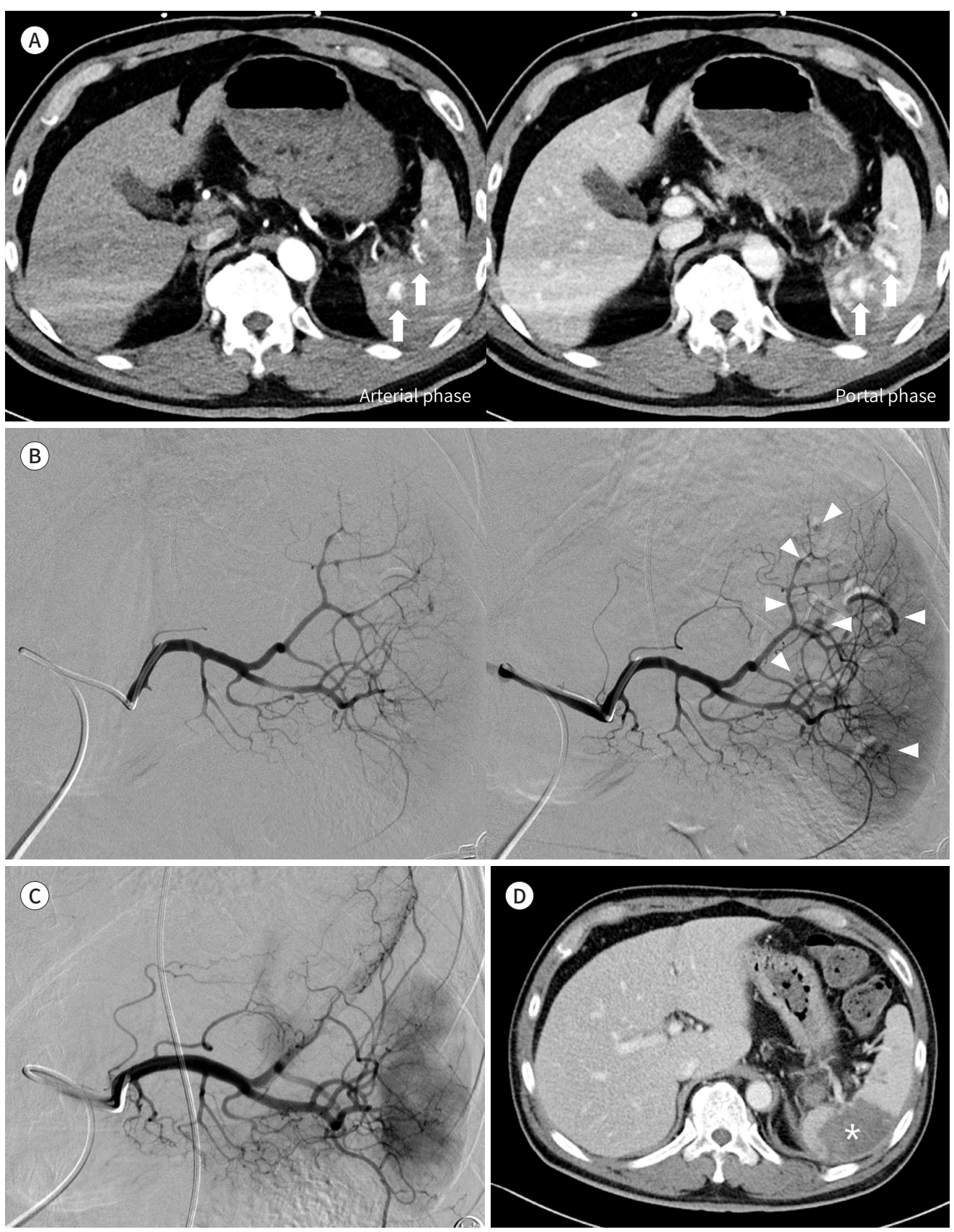
혈의 경우 문맥기나 지연기에서 조영제의 혈관 외 유출이 관찰되면서 동맥기에서는 혈관 외 유출 이 관찰되지 않아 구분할 수 있다(Fig. 2). 동맥 출혈과 정맥 출혈을 구별하는데 다중시기 촬영이 유용하다.

\section{혈종과 혈복강}

혈종은 실질 손상, 혈관 손상 모두에서 동반될 수 있다. 조영 전 CT에서 약 30 70 정도의 Hounsfield unit (이하 HU)을 가지며, 조영증강 후에는 경계가 좋지 않고 주로 고형장기의 실질보다 낮 은 음영 강도를 보인다(Fig. 3). 손상 장기 주변이나 복강 내에 액체 저류가 있는 경우 $\mathrm{HU}$ 을 측정 하여 출혈 병소를 추정할 수 있는데, 응고된 혈액은 응고되지 않은 혈액보다 높은 음영을 갖고, 출 혈 병소 근처의 혈액은 부분적으로 응고되기 때문에 높은 음영을 가지는 응고된 혈액을 찾아서 출 혈 병소를 추정한다. 이러한 소견을 전초 피덩이 징후(sentinel clot sign)라고 한다(Fig. 3) (26).

Fig. 8. Arborizing pattern of liver laceration (grade III) in a 34-year-old woman after a motor vehicle accident. The contrast-enhanced axial CT scans show multiple branching pattern lacerations more than $3 \mathrm{~cm}$ deep in liver segment 4 and the left lateral section.

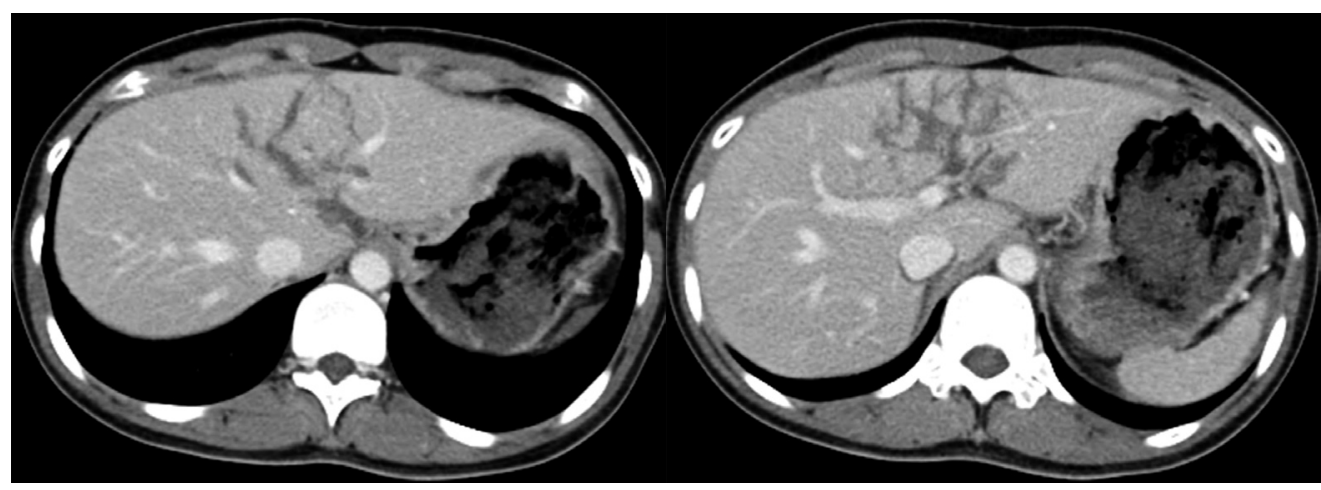

Fig. 9. Liver capsular vascular injury combined with bare area hematoma (grade III) in a 28-year-old man after a motor vehicle accident.

A. The contrast-enhanced axial CT scan shows a vascular injury (arrowhead) contained within the liver parenchyma. A bare area hematoma (asterisk) is also evident.

B. A follow-up contrast-enhanced axial CT scan acquired 8 weeks later shows a smaller bare area hematoma after conservative treatment (asterisk).
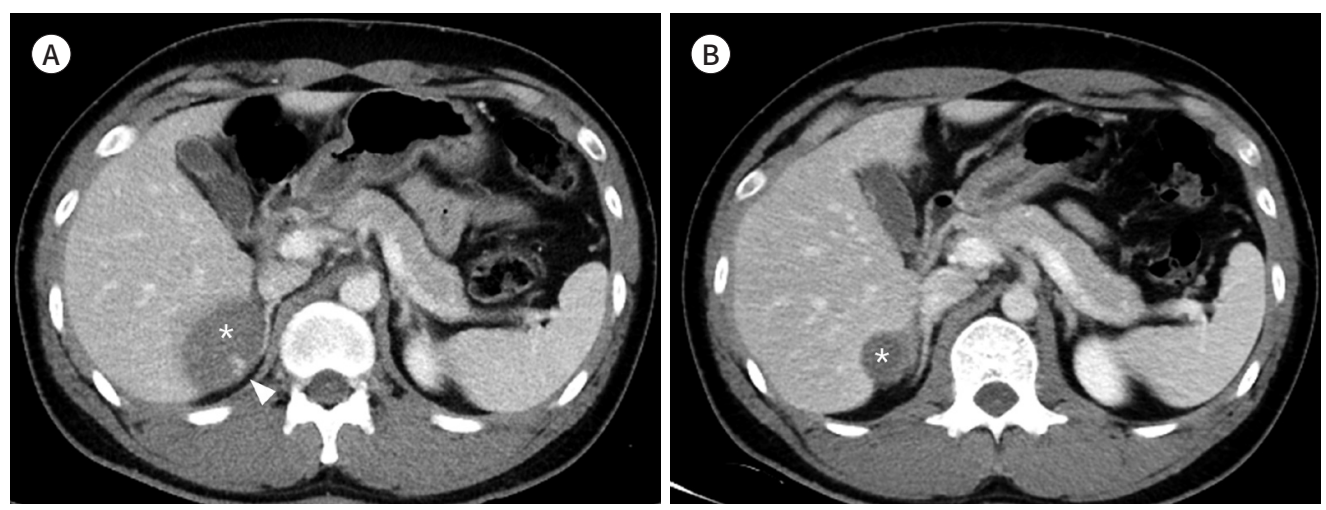


\section{비장 손상의 AAST OIS}

비장 손상의 영상 기준 등급은 피막 열상의 유무, 피막하 혈종과 실질 열상의 정도에 따라서 I-III으로 구별된다(Fig. 4) (4). 이때 비장 열상을 해부학적 변이인 비장열(splenic cleft)과 혼동하 지 말아야 하는데, 비장열은 경계가 더 명확하고 부드러운 윤곽을 가지며 내부에 지방이 있고 주

Fig. 10. Active bleeding and hemoperitoneum (grade IV) in a 56-year-old man after a pedestrian traffic accident.

A. Contrast-enhanced axial CT scans show active bleeding (arrowheads) extending beyond the liver parenchyma into the peritoneum.

B. Contrast-enhanced coronal CT scan shows active bleeding (arrowhead), a liver capsular tear (arrow), and a hemoperitoneum (asterisk).

C. Right hepatic artery angiogram shows active contrast extravasation (arrowhead) in liver segment 6.
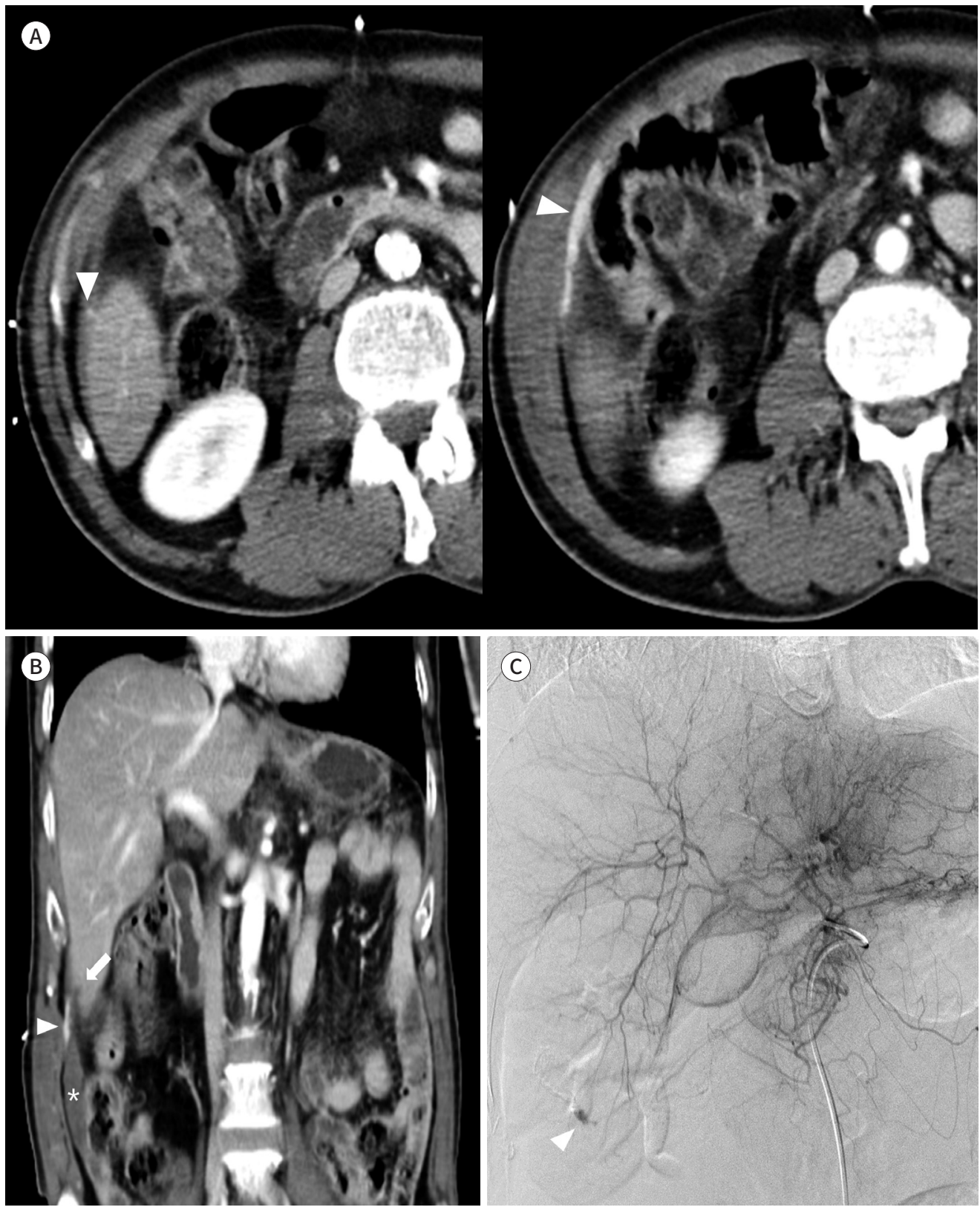
위에 혈종 동반 소견이 없다는 점이 감별점이 된다(Fig. 5).

비장 외상 환자에서 혈관 손상이 존재하면 IV 등급 이상이 되는데, 혈관 손상이나 지속적인 출 혈이 비장 피막 내에 국한되어 있으면 IV 등급이 되고(Fig. 6), 지속적인 출혈이 비장 피막을 넘어 서 복강으로 확장되면 V 등급이 된다. 실질 열상이 문부 혈관(hilar vessel)이나 분절 혈관(segmental vessel)까지 손상을 주어 비장 전체 부피의 $25 \%$ 이상의 혈류 차단을 유발하는 경우에는 $\mathrm{IV}$ 등급이 된다(Fig. 7). 산산 조각난 비장은 등급 V에 해당한다.

과거에는 혈역학적으로 불안정하거나, 안정하더라도 혈관 손상이 의심되는 외상성 비장 손상 환자의 경우 수술적인 치료 방법이 우선적으로 시행되었지만, 비장 절제 환자에 있어서 감염률과 패혈증의 위험이 증가하고, 혈액암이 증가함이 알려지면서 치료의 방향이 비장을 보존하는 방향 으로 발달해 왔다( 23,27$)$. 여전히 혈역학적으로 불안정한 경우 수술적인 치료가 우선 권고되지만, 수술을 하더라도 가능하면 비장을 보존하는 비장 구제 수술(splenic salvage operation)을 시행하 고, 혈역학적으로 안정적인 환자라면 초음파나 MDCT를 우선 시행하여 IV 등급 이상 손상인 경우 에 혈관색전술을 시행하는 것이 현재 치료의 경향이다(Fig. 7B, C) (28). 따라서 외상성 비장 손 환 자에 있어, MDCT를 통해 혈관 손상을 확인하는 것은 조기에 혈관색전술 시행을 결정하는 데 도 움을 주기 때문에 매우 중요하다.

Fig. 11. Intrahepatic venous injury (grade V) in a 46-year-old man crushed by a truck.

A. Early arterial phase contrast-enhanced axial CT scans show an extensive intraparenchymal hematoma and laceration (arrows).

B. Portal phase contrast-enhanced axial CT scan shows that the liver laceration and intraparenchymal hematoma extend into the IVC and middle hepatic vein. An IVC thrombus is noted (arrowhead).

C. Follow-up contrast-enhanced axial CT scan acquired 9 weeks after conservative treatment shows a smaller intraparenchymal hematoma (asterisk).

IVC = intrahepatic vena cava
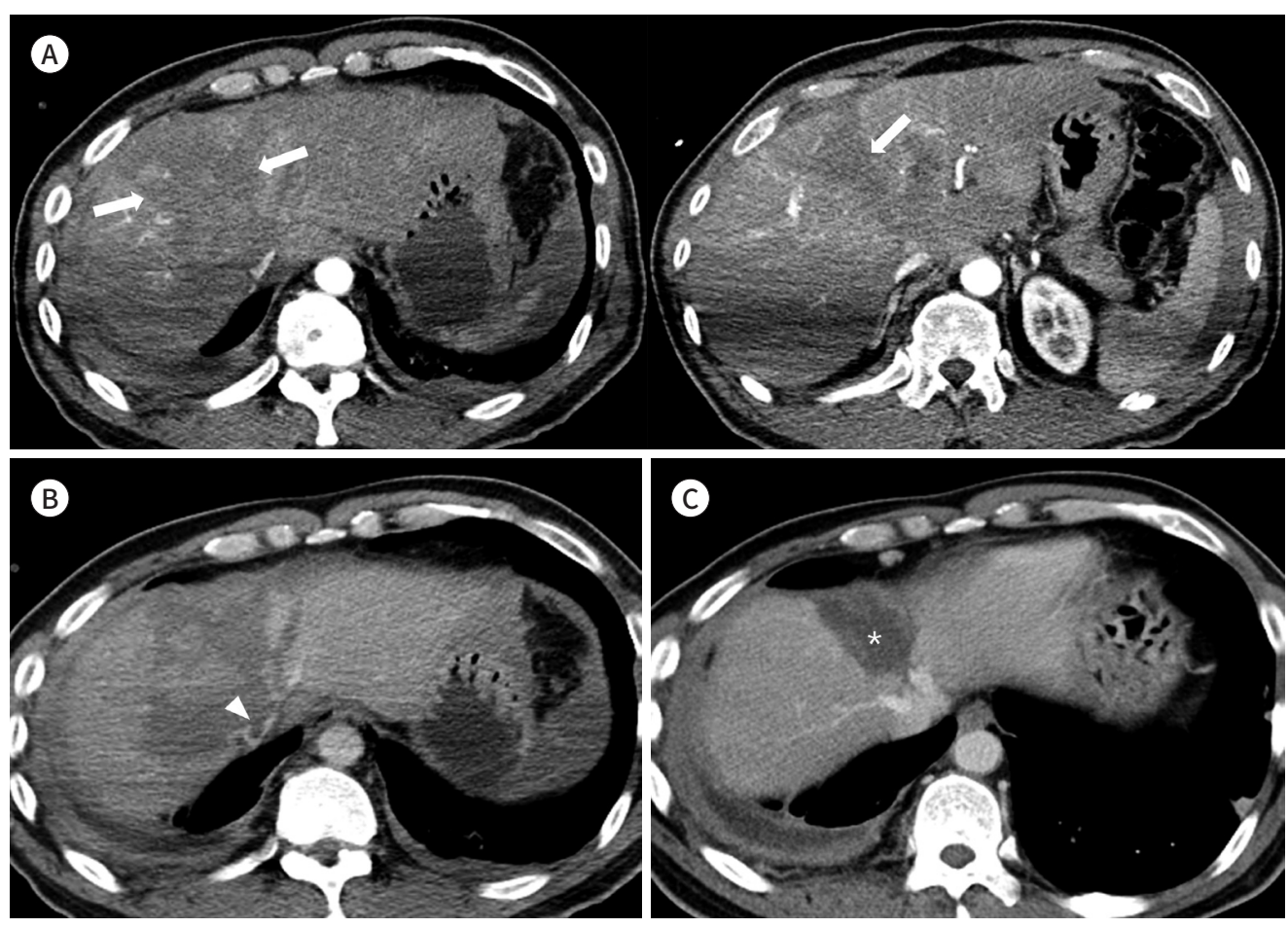


\section{간 손상의 AAST OIS}

간 손상의 영상 기준 등급 역시 피막하 혈종과 실질 열상 그리고 실질 내 혈종의 정도에 따라서 I-III으로 구별된다(Fig. 8) (4). 또한 간 피막 내에 국한된 혈관 손상이나 지속적인 출혈이 있으면 3 등급이 된다(Fig. 9).

다수의 열상으로 간 실질의 파괴가 간엽의 $25 ~ 75 \%$ 일 때는 IV 등급, $75 \%$ 이상일 때는 V 등급으 로 분류된다. 지속적인 출혈이 간 실질을 넘어 복강 내로 침범되면 IV 등급이 되고(Fig. 10), 간 실 질 내의 주요 간동맥, 간문맥 혈관이나 간 인접 하대 정맥 그리고 주요 간정맥의 손상이 동반되면 $\mathrm{V}$ 등급으로 분류된다(Fig. 11).

혈역학적으로 불안정한 외상성 간 손상 시 조기에 수술적인 치료를 하는 것이 권고되며, 혈역학 적으로 안정적인 경우 초음파 및 MDCT를 먼저 시행하여 IV 등급 이상의 손상이 있거나, 지속적 일 출혈, 거짓동맥류, 동정맥루 같은 혈관 손상이 있는 경우에는 혈관색전술을 시행한다(29). 이러 한 간 손상의 영상 분류법은 외상 환자에 있어 초기 치료를 결정하는 데 도움을 주지만, 담도 손상 이나 담즙 유출에 의한 담즙 낭종, 담즙 복막염 등 지연기 합병증에 대한 예측을 하는 데에는 큰 도 움이 되지 못한다. 따라서 간 외상 환자 분류에 있어 지연기 합병증을 조기 예측할 수 있는 방법을 모색하여, 환자의 예후를 향상시킬 수 있도록 좀 더 많은 연구가 필요하다.

Fig. 12. Renal parenchymal laceration (grade III) with perirenal hematoma in a 48-year-old woman after a motor vehicle accident.

A. Contrast-enhanced axial CT scans show a parenchymal laceration (arrowheads) and perirenal hematoma (asterisks) in the left kidney.

B. Contrast-enhanced coronal CT scan shows the parenchymal laceration (arrowhead) and perirenal hematoma (asterisk) within the Gerota fascia of the left kidney.
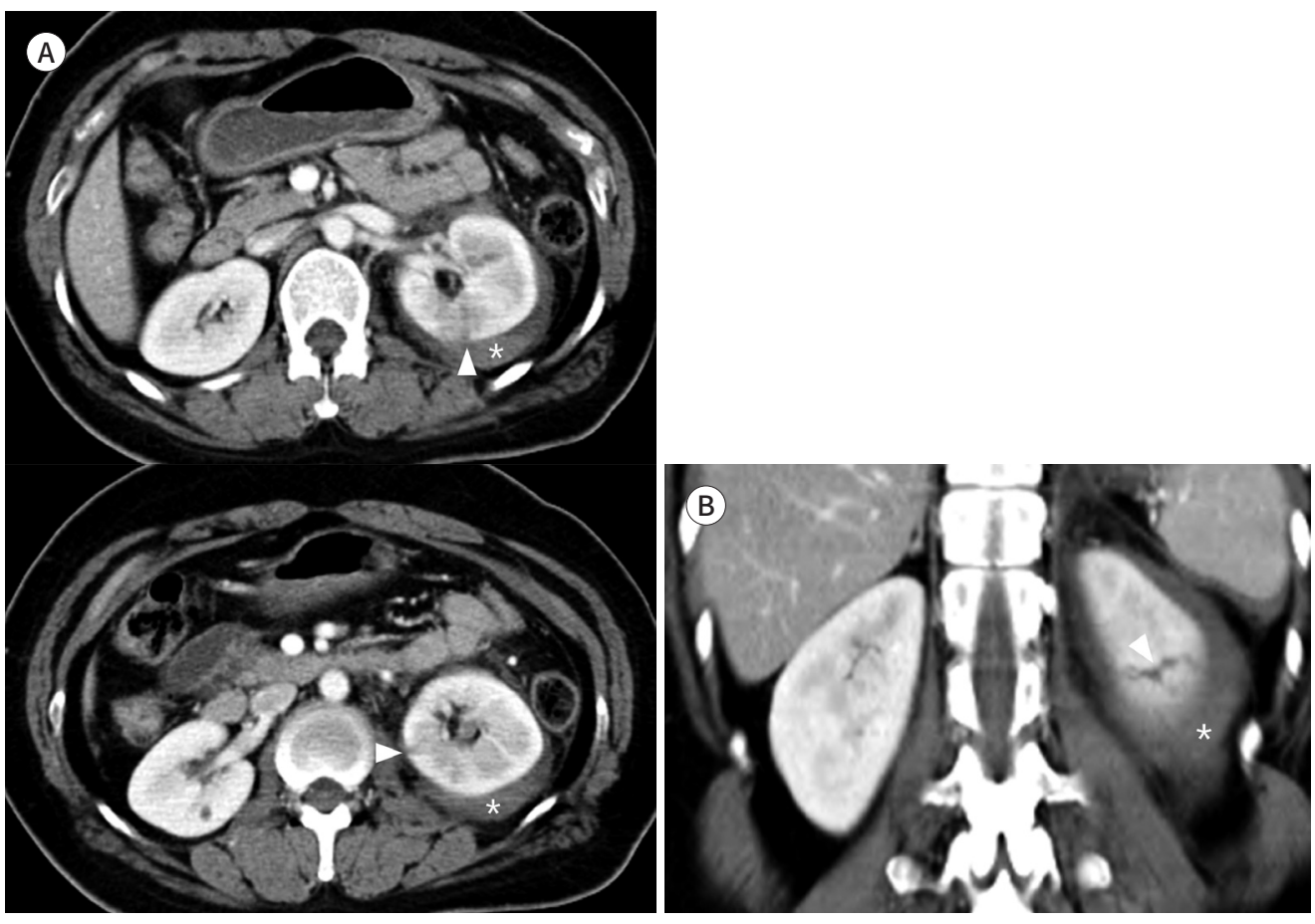


\section{신장 손상의 AAST OIS}

MDCT에서 집합관의 손상이 관찰되지 않으면서 신장근막(renal fascia) 내에 국한된 혈종이나 실질 열상은 그 정도에 따라 I, II, III 등급으로 구분된다(Fig. 12) (4). 혈관 손상이나, 지속적인 출혈

Fig. 13. Segmental kidney infarction and pelvicalyceal system injury (grade IV) in a 24-year-old man after a motor vehicle accident.

A. Arterial phase image shows segmental renal infarction with the cortical rim sign in the upper pole of the left kidney.

B. Portal phase image reveals a thrombus of the segmental artery (arrowhead) and segmental renal infarction in the left kidney.

C. Follow-up contrast-enhanced coronal CT scan acquired 2 weeks later shows the parenchymal laceration (arrowhead) combined with an increased perirenal fluid collection (asterisks) suggestive of a pelvicalyceal system injury and urinoma.

D. In the follow-up pyelogram acquired 2 weeks later, urinary extravasation (arrowheads) is noted from the damaged pelvocalyceal system of the left kidney.
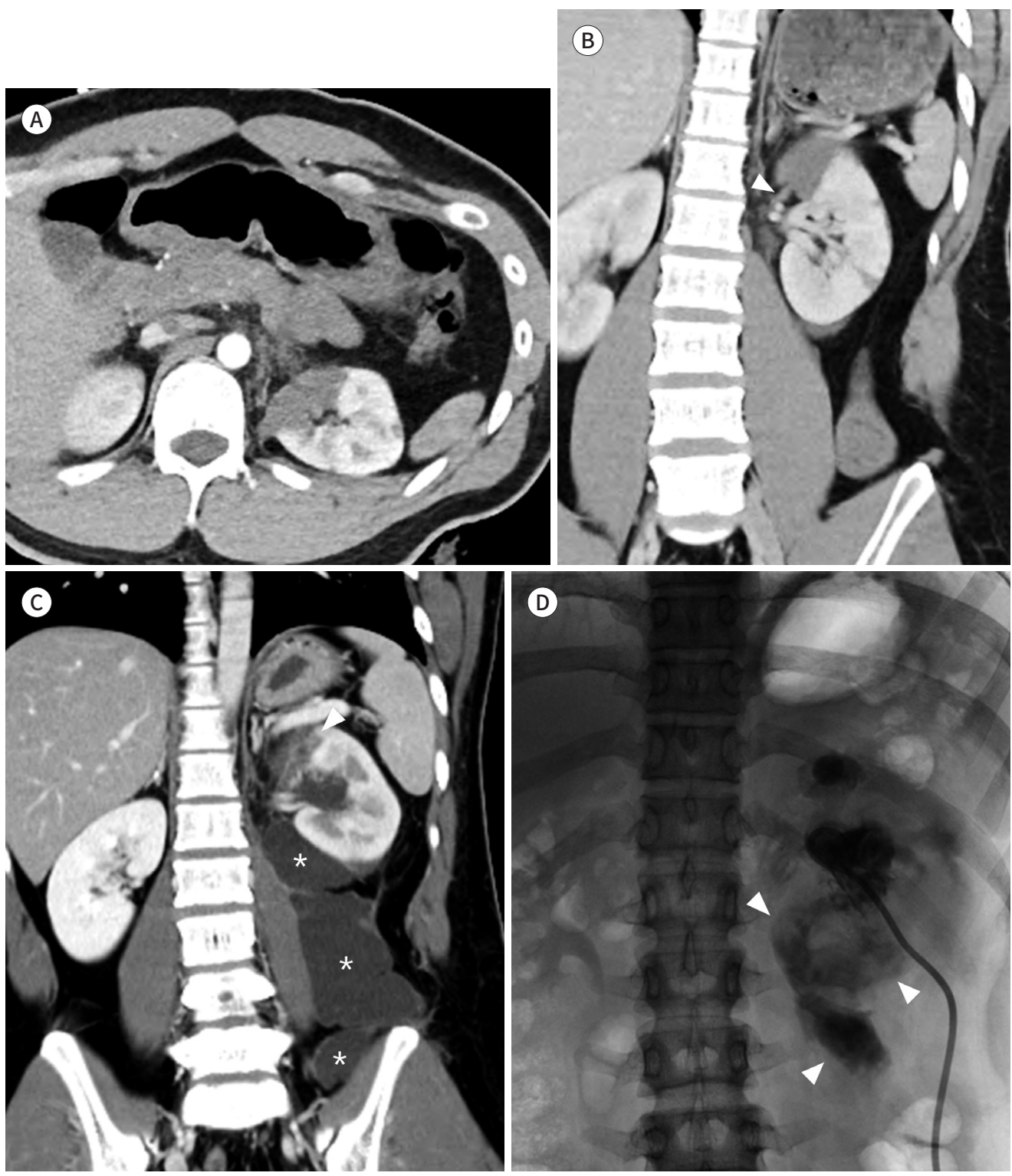
이 있더라도 신장근막 내에 국한되어 있으면 III 등급에 해당된다. 실질 열상이 집합계의 손상을 가져오거나, 신우의 열상, 요관 깔때기의 손상(ureteropelvic junction)이 있으면 IV 등급에 해당 한다(Fig. 13). 또한 분절 신장 정맥이나 동맥의 손상이 있거나 혈전에 의한 분절성 혹은 완전한 신 장 경색 동반 시에도 IV 등급이 된다(Fig. 13). 주요 신장 동맥이나 정맥의 열상 혹은 문부의 찢김 (hilum avulsion)이 있으면 V 등급이 되고, 신장 경색과 함께 지속적인 출혈이 동반되어도 V 등급 이 된다. 신장의 실질이 산산 조각 나서 정상 실질을 구별할 수 없는 경우에도 V 등급에 해당한다 (Fig. 14).

신장 손상의 영상 등급은 OIS 2018 개정안에서 가장 많은 변화가 있는 장기이다. 특히 IV 등급과 $\mathrm{V}$ 등급에서 많은 변화가 있는데, 신장의 외상성 손상의 기본 치료 방침은 보존적인 치료이지만, IV 등급 이상의 혈관 손상 혹은 집합관의 손상이 동반되면 혈관색전술, 비뇨기적 중재술 혹은 수 술적인 치료가 필요하기 때문이다. 따라서 MDCT를 통해 이를 구별해내는 것이 중요하며, 이를 위해서는 신장 외상성 환자에서는 반드시 5 분 지연기 영상을 얻어야 한다.

\section{결론}

외상에 의한 복부고형장기의 손상은 매우 다양한 스펙트럼을 가진다. 외상 환자의 치료 방향 결정 및 더 나은 예후를 위해 MDCT의 역할은 점점 그 중요성이 커지고 있다. 따라서 영상의학과 의사가 정확한 외상 환자의 중증도 분류에 도움을 주기 위해서는 새로 개정된 OIS 체계와 관련된 $\mathrm{MDCT}$ 소견의 이해가 필수적이다. 이러한 이해를 바탕으로 수술적인 치료나 응급한 혈관색전술

Fig. 14. Renal hilar injury with ACE and devascularized kidney (grade V) in a 17-year-old man after a motorcycle accident.

A. Arterial phase contrast-enhanced axial CT scan shows a pedicle injury (arrowhead).

B. Portal phase contrast-enhanced coronal CT scan shows ACE in the left renal pedicle (arrowhead) with complete devascularization of the left kidney and a large subcapsular hematoma. An associated spleen injury (grade $\mathrm{V}$ ) is also noted.

$\mathrm{ACE}=$ active contrast extravasation
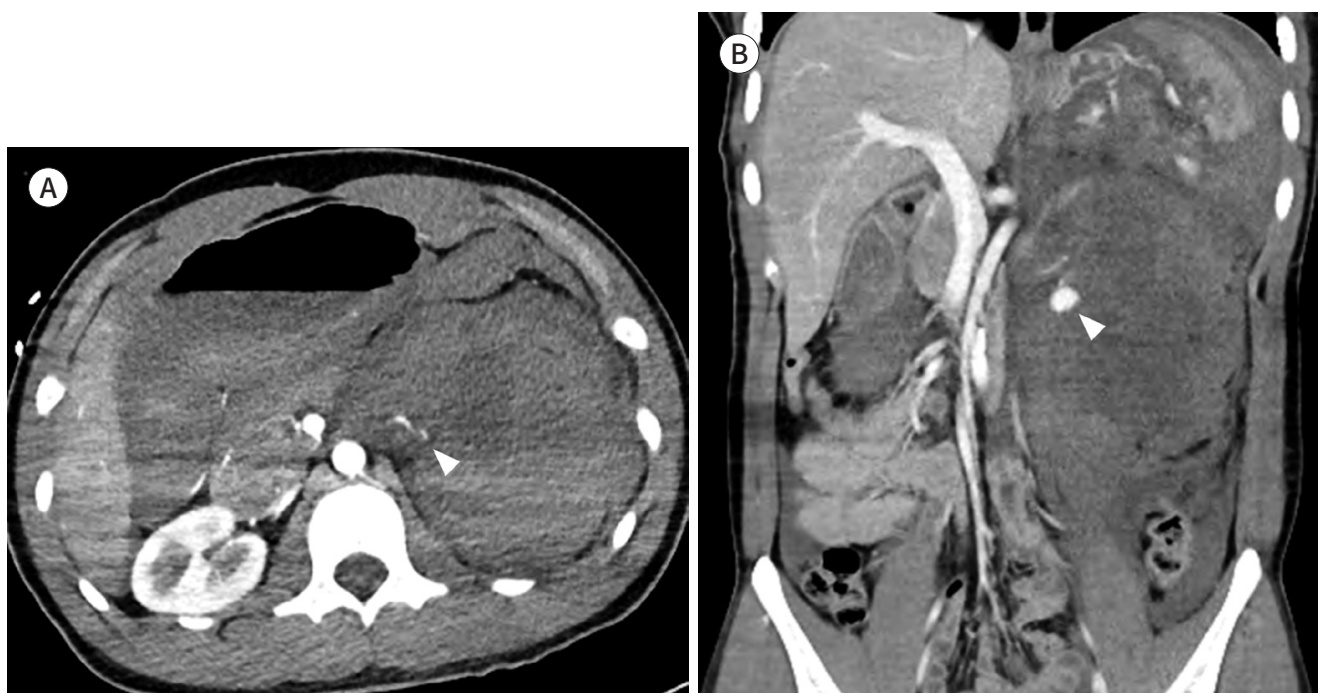
이 필요한 환자를 선별할 수 있어야 한다. 따라서 앞으로 2018년 개정된 OIS 등급에 따른 표준 치 료 전략의 정립이 필요하며, 이를 위해 추가적인 연구들이 필요할 것으로 생각된다.

\section{Author Contributions}

Conceptualization, L.S.L.; data curation, L.S.L.; investigation, all authors; project administration, S.S.W.; resources, L.S.L., Y.H.H.; supervision, K.Y.M., S.S.W.; visualization, W.Y.D., L.S.L., Y.H.H.; writing-original draft, L.S.L., Y.H.H.; and writing-review \& editing, W.Y.D.

\section{Conflicts of Interest}

The authors have no potential conflicts of interest to disclose.

\section{REFERENCES}

1. Moore EE, Shackford SR, Pachter HL, McAninch JW, Browner BD, Champion HR, et al. Organ injury scaling: spleen, liver, and kidney. J Trauma 1989;29:1664-1666

2. Moore EE, Cogbill TH, Jurkovich GJ, Shackford SR, Malangoni MA, Champion HR. Organ injury scaling: spleen and liver (1994 revision). J Trauma 1995;38:323-324

3. Shafi S, Aboutanos M, Brown CV, Ciesla D, Cohen MJ, Crandall ML, et al. Measuring anatomic severity of disease in emergency general surgery. J Trauma Acute Care Surg 2014;76:884-887

4. Kozar RA, Crandall M, Shanmuganathan K, Zarzaur BL, Coburn M, Cribari C, et al. Organ injury scaling 2018 update: Spleen, liver, and kidney. J Trauma Acute Care Surg 2018;85:1119-1122

5. Boscak AR, Shanmuganathan K, Mirvis SE, Fleiter TR, Miller LA, Sliker CW, et al. Optimizing trauma multidetector CT protocol for blunt splenic injury: need for arterial and portal venous phase scans. Radiology 2013;268:79-88

6. Gavant ML, Schurr M, Flick PA, Croce MA, Fabian TC, Gold RE. Predicting clinical outcome of nonsurgical management of blunt splenic injury: using CT to reveal abnormalities of splenic vasculature. AJR Am J Roentgenol 1997;168:207-212

7. Saksobhavivat N, Shanmuganathan K, Chen HH, DuBose JJ, Richard H, Khan MA, et al. Blunt splenic injury: use of a multidetector CT-based splenic injury grading system and clinical parameters for triage of patients at admission. Radiology 2015;274:702-711

8. Shanmuganathan K, Mirvis SE, Boyd-Kranis R, Takada T, Scalea TM. Nonsurgical management of blunt splenic injury: use of $\mathrm{CT}$ criteria to select patients for splenic arteriography and potential endovascular therapy. Radiology 2000;217:75-82

9. Charbit J, Manzanera J, Millet I, Roustan JP, Chardon P, Taourel P, et al. What are the specific computed tomography scan criteria that can predict or exclude the need for renal angioembolization after high-grade renal trauma in a conservative management strategy? J Trauma 2011;70:1219-1227; discussion 1227-1228

10. Chiron P, Hornez E, Boddaert G, Dusaud M, Bayoud Y, Molimard B, et al. Grade IV renal trauma management. A revision of the AAST renal injury grading scale is mandatory. Eur J Trauma Emerg Surg 2016;42: 237-241

11. Dugi DD 3rd, Morey AF, Gupta A, Nuss GR, Sheu GL, Pruitt JH. American Association for the Surgery of Trauma grade 4 renal injury substratification into grades 4a (low risk) and 4b (high risk). J Urol 2010;183:592-597

12. Green CS, Bulger EM, Kwan SW. Outcomes and complications of angioembolization for hepatic trauma: a systematic review of the literature. J Trauma Acute Care Surg 2016;80:529-537

13. Keihani S, Xu Y, Presson AP, Hotaling JM, Nirula R, Piotrowski J, et al. Contemporary management of highgrade renal trauma: results from the American Association for the Surgery of Trauma Genitourinary Trauma study. J Trauma Acute Care Surg 2018;84:418-425

14. Lee YH, Wu CH, Wang LJ, Wong YC, Chen HW, Wang CJ, et al. Predictive factors for early failure of transarterial embolization in blunt hepatic injury patients. Clin Radiol 2014;69:e505-511

15. Letoublon C, Morra I, Chen Y, Monnin V, Voirin D, Arvieux C. Hepatic arterial embolization in the management of blunt hepatic trauma: indications and complications. J Trauma 2011;70:1032-1036; discussion 1036-1037

16. Marmery H, Shanmuganathan K, Alexander MT, Mirvis SE. Optimization of selection for nonoperative man- 
agement of blunt splenic injury: comparison of MDCT grading systems. AJR Am J Roentgenol 2007;189: $1421-1427$

17. Marmery H, Shanmuganathan K, Mirvis SE, Richard H 3rd, Sliker C, Miller LA, et al. Correlation of multidetector CT findings with splenic arteriography and surgery: prospective study in 392 patients. J Am Coll Surg 2008;206:685-693

18. Melloul E, Denys A, Demartines N. Management of severe blunt hepatic injury in the era of computed tomography and transarterial embolization: a systematic review and critical appraisal of the literature. J Trauma Acute Care Surg 2015;79:468-474

19. Misselbeck TS, Teicher EJ, Cipolle MD, Pasquale MD, Shah KT, Dangleben DA, et al. Hepatic angioembolization in trauma patients: indications and complications. J Trauma 2009;67:769-773

20. Nuss GR, Morey AF, Jenkins AC, Pruitt JH, Dugi DD 3rd, Morse B, et al. Radiographic predictors of need for angiographic embolization after traumatic renal injury. J Trauma 2009;67:578-582; discussion 582

21. Shariat SF, Roehrborn CG, Karakiewicz PI, Dhami G, Stage KH. Evidence-based validation of the predictive value of the American Association for the Surgery of Trauma kidney injury scale. J Trauma 2007;62:933-939

22. Zarzaur BL, Dunn JA, Leininger B, Lauerman M, Shanmuganathan K, Kaups K, et al. Natural history of splenic vascular abnormalities after blunt injury: A Western Trauma Association multicenter trial. J Trauma Acute Care Surg 2017:83:999-1005

23. Zarzaur BL, Kozar R, Myers JG, Claridge JA, Scalea TM, Neideen TA, et al. The splenic injury outcomes trial: an American Association for the Surgery of Trauma multi-institutional study. J Trauma Acute Care Surg 2015; $79: 335-342$

24. Leung V, Sastry A, Woo TD, Jones HR. Implementation of a split-bolus single-pass CT protocol at a UK major trauma centre to reduce excess radiation dose in trauma pan-CT. Clin Radiol 2015;70:1110-1115

25. Lee J, Ahn JH. Multidetector CT in blunt abdominal trauma: imaging findings and pitfalls. J Korean Soc Radiol 2019;80:445-465

26. Orwig D, Federle MP. Localized clotted blood as evidence of visceral trauma on CT: the sentinel clot sign. AJR Am J Roentgenol 1989;153:747-749

27. Schweizer W, Böhlen L, Dennison A, Blumgart LH. Prospective study in adults of splenic preservation after traumatic rupture. Br J Surg 1992;79:1330-1333

28. Coccolini F, Montori G, Catena F, Kluger Y, Biffl W, Moore EE, et al. Splenic trauma: WSES classification and guidelines for adult and pediatric patients. World J Emerg Surg 2017;12:40

29. Coccolini F, Catena F, Moore EE, Ivatury R, Biffl W, Peitzman A, et al. WSES classification and guidelines for liver trauma. World J Emerg Surg 2016;11:50 
2018 개정 미국외상수술협회 복부고형장기 손상척도에 따른 다중검출 $\mathrm{CT}$ 소견

유효현· 원유동*·이수림·구영미· 송선화

2018년에 새롭게 개정된 장기 손상척도는 이전 미국외상수술협회의 응급수술분류체계와 유 사한 형식을 가지며, 고형장기 손상의 등급을 지정하는 기준을 영상(imaging), 수술(operative), 병리(pathologic) 세 가지 세트로 나누어 분류하였다. 2018년 개정에서 가장 중요한 변 화는 거짓동맥류와 동정맥 누공을 포함한 혈관 손상의 다중검출CT (multidetector CT; 이하 $\mathrm{MDCT}$ ) 소견을 정의하여 장기 손상척도에 통합한 것이다. 이전 장기 손상척도와 동일하게 세 가지 기준 중에 가장 높은 등급이 최종 등급이 된다. 또한 한 장기 내에 여러 개의 1 등급 또 는 2 등급 소견이 있으면, 다발성 손상에 대해 3 등급의 부여가 가능하다. 본 임상화보에서는 2018년 개정된 미국외상수술협회 장기 손상척도의 MDCT 소견을 소개하고자 한다.

가톨릭대학교 의정부성모병원 영상의학과 